Proceedings of the 2018 International Scientific Conference 'Economic Sciences for Agribusiness and Rural Economy' No 1, Warsaw, 7-8 June 2018, pp. 68-74

\title{
ENVIRONMENTAL AWARENESS OF POLISH FARMERS PARTICIPATING IN FADN
}

\author{
Anna Kłoczko-Gajewska, $\mathrm{PhD}^{1}$; Piotr Sulewski, $\mathrm{PhD}^{2}$
}

Faculty of Economic Sciences, Warsaw University of Life Sciences - SGGW

\begin{abstract}
A prerequisite to manage farms in line with the sustainability concept is to be aware of the potential impact of farming practices on environmental and social issues. In this paper we tried to describe and assess environmental awareness of Polish farmers. Basing on the representative sample of 600 farms participating in the FADN we have carried out interviews concerning the farmers' awareness of environmental problems and potential influence of farming practices on the natural environment, as well as the concept of sustainable agriculture. The results show that the farmers have a relatively high environmental awareness (at least in declarations). Farmers with higher economic potential and participating in agri-environmental schemes are more likely to know the concept of sustainable farming, than the remaining ones.
\end{abstract}

Keywords: sustainable development, farmers, environmental awareness

JEL code: Q01

\section{INTRODUCTION}

The concept of sustainable development became a popular topic for discussions of economists and politicians after the Report of the World Commission on Environment and Development 'Our Common Future' was published. The report contained one of the most commonly used definition of sustainable development: 'to ensure that it meets the needs of the present without compromising the ability of future generations to meet their own needs' (World Commission on Environment and Development, 1987). Implementing this concept in reality is still a challenge and agriculture is no exception. Being aware of the importance of considering jointly economic, en- vironmental, and social issues, in this paper we will focus on the environmental aspect of the problem.

The impact of agriculture on the environment is already widely recognised, because agriculture can produce both positive and negative environmental externalities (Zegar, 2017). It is enough to say that the Agenda 2000 reform of the Common Agricultural Policy made agri-environment measures an obligatory part of the Rural Development Programmes (RDP) of the EU-27 Member States (van Herzele et al., 2013). Of course, the most important decisions and actions that directly affect natural environment are made by the farmers. According to the knowledge approach to sustainable agriculture, the key factor influencing practical implementation of sustainable development

${ }^{1}$ Corresponding author: Nowoursynowska 166, 02-787 Warsaw, Poland, anna_kloczko_gajewska@sggw.pl, $+48225934029$

${ }^{2}$ Corresponding author: Nowoursynowska 166,02-787 Warsaw, Poland, piotr_sulewski@sggw.pl, +4822 5934217 
in farming is the farmer's knowledge (Carreón et al., 2011). When the knowledge is sufficient, its practical implementation becomes an issue. If the policymakers want to achieve permanent environmental improvements, they need to strengthen the farmers' internal motivation for environmental objectives (van Herzele et al., 2013).

It is not only a common-sense knowledge, that 'farmers make land-use decisions not only in a business context but also in a personal context (...). It relates to individual and social conditions in which the farmer operates, including personal capabilities such as knowledge, skills and power, and attitudinal and psychological dimension' (Greiner, 2015). 'A farmer (...) will weigh up all the influences on him from policy, advisory services, society, his family, friends, peers, the media and based on all these influences and the information available to him forms his beliefs' (Beedell and Rehman, 1999). It is quite obvious that any purposive action has to begin with the awareness of the problem and its causes. Even though the awareness itself does not mean that the farmers will comply with environmental standards, the awareness of the problem play a role in influencing behaviour (Okumah, Martin-Ortega and Novo, 2018). Thus the goal of this paper is to describe and assess the environmental awareness of Polish farmers, especially concerning the farmers' perception of the changes in natural environment in their place of living as well as of potential impact of farming practices on the environment.

\section{MATERIALS AND METHODS}

The research was carried out in farms that participate in Polish FADN (Farm Accountancy Data Network). Generally, the Polish FADN sample consists of over 11.1 thousand farms that represent about 730 thousand farms producing for the market. For the purpose of this study a subsample of 600 farms was chosen, considering their representativeness in specialisa- tion of production, standard output, and region, with the use of the Neyman method (FADN, 2008; Was, 2013). The subsample is representative to the Polish FADN sample. The FADN database covers such topics as costs, production, financial result, and basic organisational issues of the farms. In 2017, additional information concerning, among others, environmental awareness of the farmers was collected with the use of face-to face interviews.

\section{RESULTS}

One of the key issues that is to be faced by agricultural producers is adapting to the changing natural conditions, resulting from climate changes. The first step to adapt is to observe these changes. According to our analysis the vast majority of the farmers did notice climate changes in their place of living within their lifetime. They were asked to assess these changes using the scale from -5 (significant worsening) to +5 (significant improvement), and the average answer was -1.86 . The distribution of answers is given on Figure 1. It is worth emphasizing that merely few farmers noticed positive changes, while almost $15 \%$ of farmers observed visibly negative changes (joint answers -4 and -5 ).

Figure 2 contains information on particular aspects of climate changes observed by interviewed farmers. The most common answers were: lower precipitation in wintertime and higher temperatures in winter, while longer growing season was the least popular answer.

Most of the respondents said that within their lifetimes the state of the natural environment in their surroundings did not change significantly (Fig. 3$)^{3}$.

Undoubtedly, farmers' managerial decisions have a significant impact on the natural environment. Improper farming procedures can cause a rise of $\mathrm{GHG}$ emissions, decline in biodiversity, eutrophication of the water body, etc. Our analysis shows that most of the farmers are aware of their potentially negative impact

${ }^{3}$ A study carried out by Sullivan et al. (1996) in Michigan on a sample of 13 conventional and 12 organic farmers revealed, that the farmers observe the nature rather closely. In the scale from 1 (not at all) to 5 (very closely) the averages were the following: rainfall (4.84), soil quality (4.76), soil erosion (4.68), change of seasons (4.4), wildlife (4.24), water quality (4.24), insect populations (4.04), cloud types (3.72). 


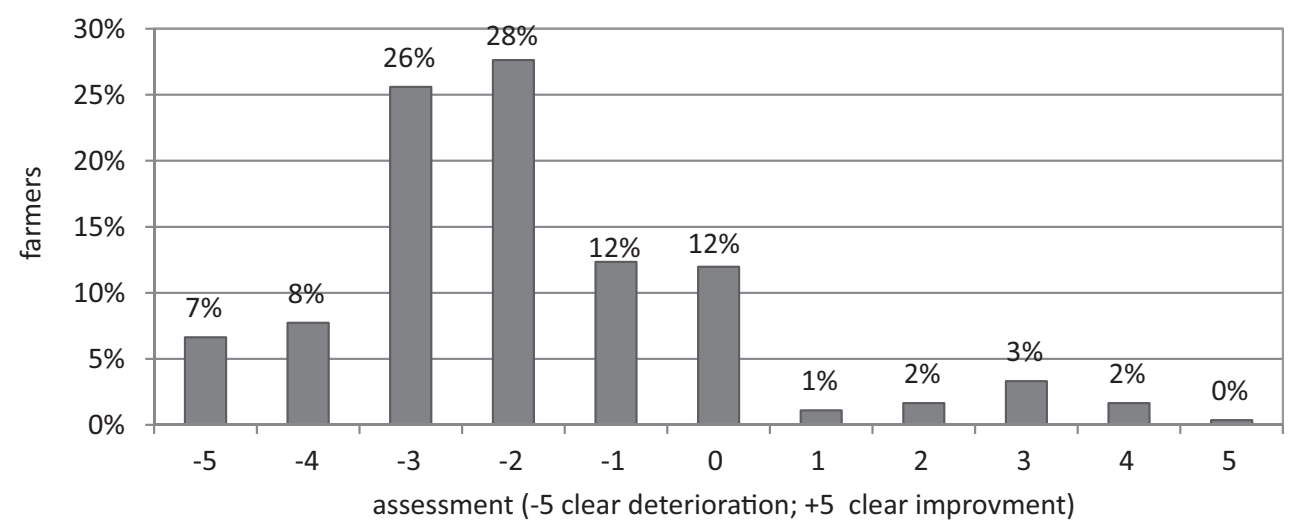

Figure 1. The farmers' assessment of climate changes in their place of living within their lifetimes Source: own research.

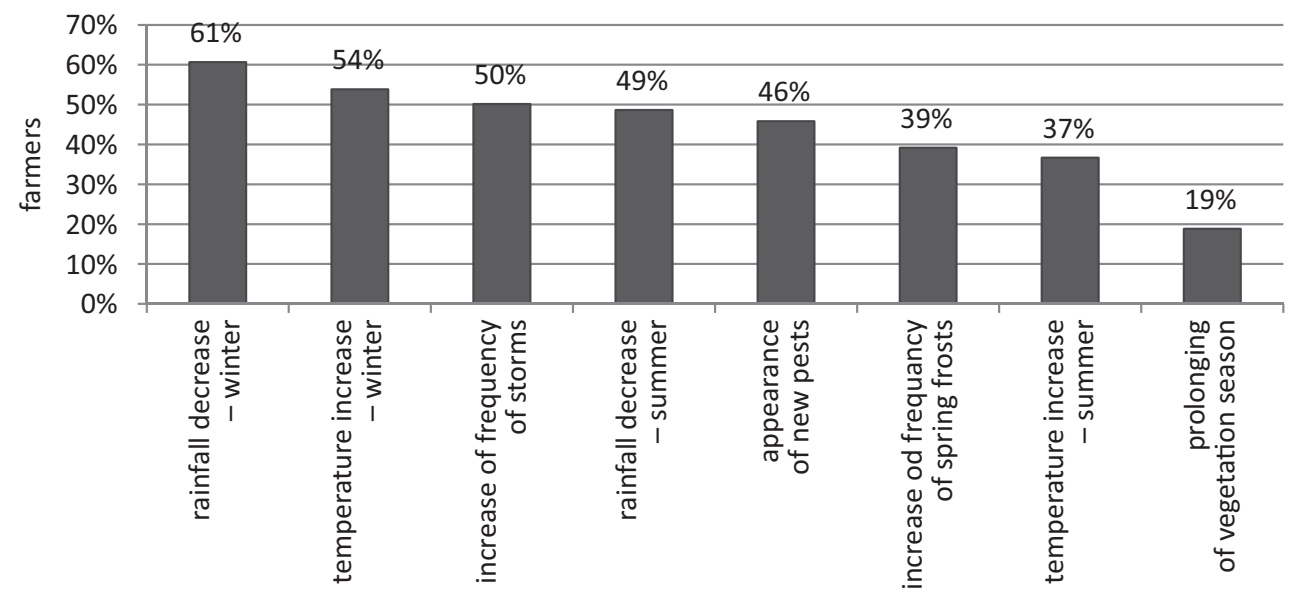

Figure 2. The farmers' observation of different aspects of climate changes in their place of living within their lifetimes

Source: own research.

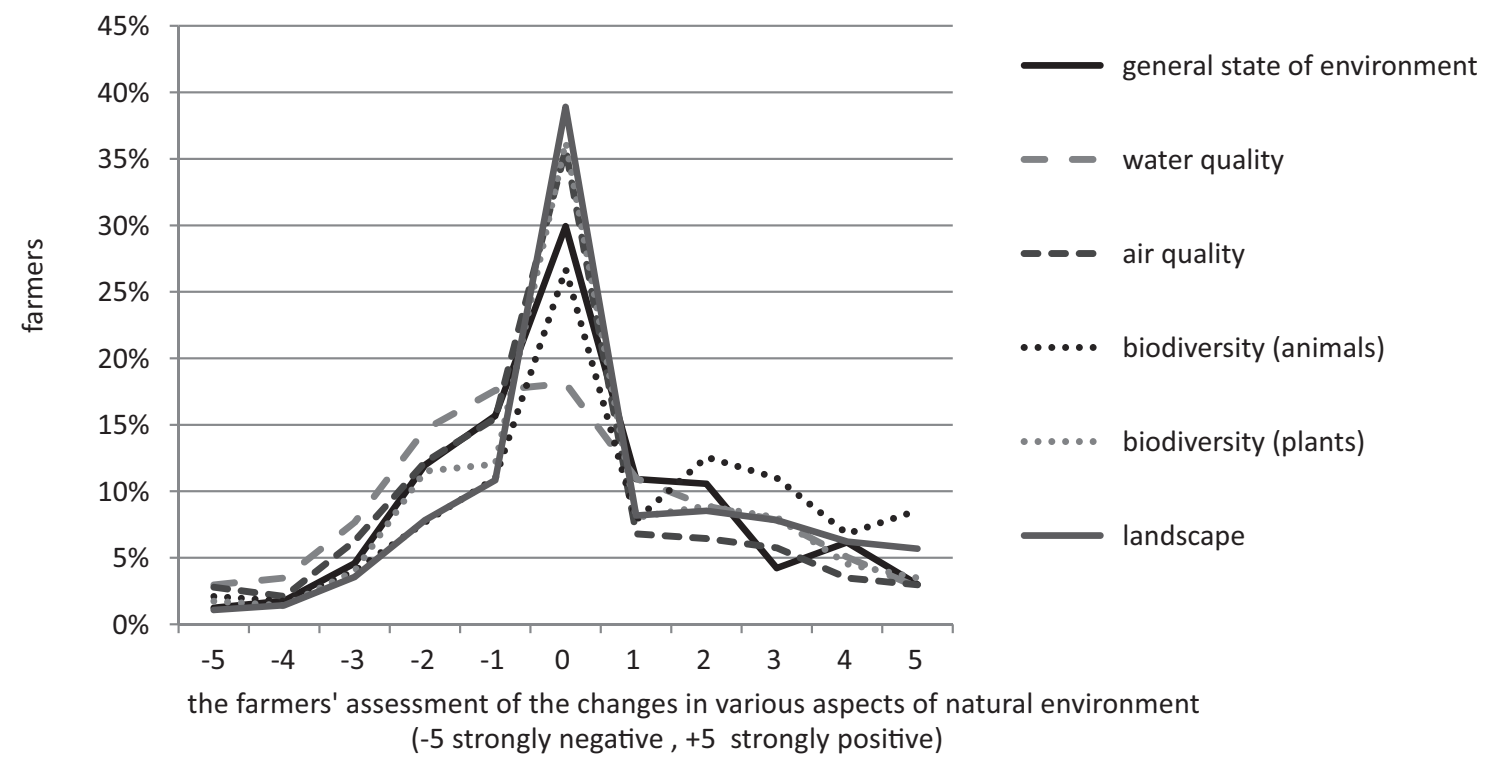

Figure 3. The farmers' assessment of the changes in various aspects of natural environment Source: own research. 
on the natural environment (Fig. 4). This is a positive information, because earlier research showed rather low environmental awareness of the farmers (Majewski, 2001). In 2009 about $1 / 4$ of farmers from a commune in Mazowsze region claimed that farming cannot pollute the environment, and the answers did not differ depending on the level of education (Kałuża, 2009). This change in time could be partly explained by EU's environmental policy toward agriculture (for example reducing single-area payments if the farmers did not follow the cross-compliance or giving a possibility to participate in agri-environmental schemes). Although almost half of the farmers assessed environmental impact of farming as neutral (marked as 0 ), at the same time more farmers see their potential impact as negative than as positive.
Not only are the farmers aware of the impact of the agriculture on the natural environment, but also most of them have heard of sustainable agriculture. As Table 1 shows, 77\% of the farmers declare they have heard this term, while only $14 \%$ denied it (9\% were not sure whether they have heard it or not). Moreover, vast majority of those that have heard of sustainable agriculture were also able to choose its general goals from a given set of answers. Considering jointly economic, ecological, and environmental issues was chosen by $67 \%$ of the respondents, and as many as $74 \%$ chose the answer that sustainable agriculture is a way of farming that allows to keep the environment in good condition for future generations. In general, almost $98 \%$ of those declaring that they knew the concept of sustainable develop-

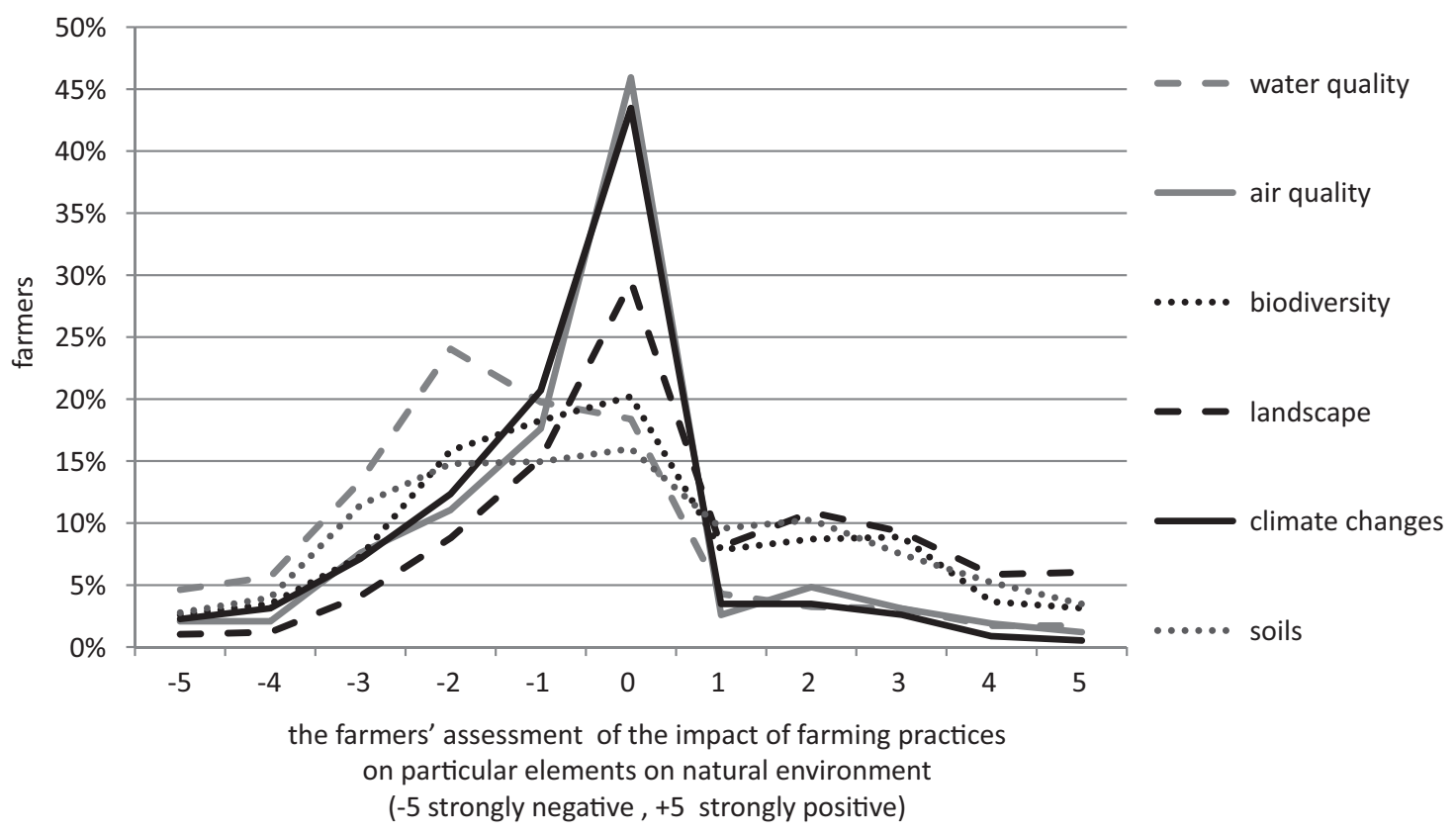

Figure 4. The farmers' assessment of the impact of farming practices on particular elements on natural environment Source: own research.

\footnotetext{
${ }^{4}$ In the research carried out in 2007 on a small sample of 100 farmers living in commune Sarnaki in Mazowsze region knowledge of this term was declared by $85 \%$ of the respondents (Kałuża, 2009). Another research, carried out on a sample of 100 visiting Regional Exhibition of Farm Animals in Podkarpacie region showed that $78 \%$ of interviewed farmers have heard the term 'sustainable development'. At the same time $82 \%$ of them correctly defined agri-environmental measures, $64 \%$ could give actions within these programs., and only $56 \%$ were able to correctly define the code of good agricultural practice (Kostecka and Mroczek, 2007).
} 
Proceedings of the 2018 International Scientific Conference 'Economic Sciences for Agribusiness and Rural Economy' No 1, Warsaw, 7-8 June 2018, pp. 68-74

Table 1. The comparison of the farmers depending on their knowledge of the term 'sustainable farming'

\begin{tabular}{|c|c|c|c|c|c|c|}
\hline \multirow{2}{*}{ Specification } & \multirow{2}{*}{ Units } & \multicolumn{3}{|c|}{$\begin{array}{c}\text { Have you heard of } \\
\text { 'sustainable agriculture'? }\end{array}$} & \multirow{2}{*}{ SD } & \multirow{2}{*}{$\begin{array}{r}\text { Total } \\
\text { sample }\end{array}$} \\
\hline & & yes & no & $\begin{array}{l}\text { don't } \\
\text { know }\end{array}$ & & \\
\hline Share of farmers in the sample & $\%$ & 77 & 14 & 9 & - & 100 \\
\hline $\begin{array}{l}\text { Share of farmers participating } \\
\text { in agri-environmental schemes }\end{array}$ & $\%$ & 46 & 23 & 25 & - & 41 \\
\hline Agricultural land & ha & 39 & 27 & 25 & 49 & 36 \\
\hline Soil quality & soil quality indicator* & 1.07 & 0.80 & 0.74 & 0.34 & 1.00 \\
\hline Total production & PLN thous. & 262 & 218 & 176 & 419 & 248 \\
\hline Farm income & PLN thous. & 83 & 53 & 56 & 129 & 76 \\
\hline Own capital & PLN thous. & 1304 & 996 & 913 & 1310 & 1226 \\
\hline Livestock & LU & 30 & 35 & 21 & 57 & 30 \\
\hline Costs of mineral fertilisers & PLN thous. $/ \mathrm{km}^{2}$ & 69.3 & 95.2 & 76.9 & 99.1 & 78 \\
\hline Cost of chemical crop protection & PLN thous. $/ \mathrm{km}^{2}$ & 29.9 & 23.7 & 39.8 & 64.3 & 29.9 \\
\hline Time of work in agriculture & years & 28 & 27 & 27 & 11 & 28 \\
\hline Time of managing a farm & years & 22 & 21 & 21 & 10 & 21 \\
\hline Share of farmers with university degree & $\%$ & 17 & 12 & 9 & - & 16 \\
\hline Share of farmers after secondary school & $\%$ & 44 & 44 & 47 & - & 44 \\
\hline Share of farmers after vocational school & $\%$ & 35 & 41 & 42 & - & 36 \\
\hline Share of farmers with agricultural education & $\%$ & 62 & 66 & 63 & - & 63 \\
\hline Heard complaints that the farm was onerous & $\%$ & 10 & 12 & 11 & - & 11 \\
\hline
\end{tabular}

* The soil quality indicator describes the quality of soils at farm level and reflects the relations of 'comparative fiscal hectare' to physical hectares. This value is determined on the basis of surface area, type and class of farmland based on the land register as well as additions to district of taxes. Value of soil quality index equal 1 reflects approximately average quality of soils in the region.

Source: own research.

ment were able to choose correctly at least one of its features.

Relatively few farmers chose incorrect answers such as 'treating environment as more important than the financial result' or 'sustainable agriculture means organic farming'. To sum up, the farmers' awareness is rather satisfactory. However, we need to remember that the FADN sample covers only farms producing for the market, and not subsistence farms. This might result in a bias toward higher awareness in agro-environmental issues.
There are some significant differences between the farmers that have heard of sustainable agriculture and those who have not. The former have twice as many times took part in agri-environmental measures as the latter (46 and $23 \%$, respectively). It is quite obvious that participating in such plans requires some knowledge of agro-environmental issues, sustainable agriculture among them. Moreover, the farmers who declared knowledge of sustainable agriculture were the owners of farms with relatively higher economic potential: the agricultural land of their farms was two 
times higher than in the other group. It is worth noting that the share of relatively large farms applying for agro-environmental schemes in Rural Development Plan 2004-2006 was visibly higher than in the whole country, and the average size of farms applying for funds raised in RDP 2007-2013 (Kociszewski, 2013). Kociszewki (2013) suggested that some of the largest farms could apply for the funds for the land that was not under production anyway. If that was right, participation in the scheme did not affect the natural environment. Newby et al. (1977, cited after Beedell and Rehman, 1999) noticed that farm size could not explain farmers' attitudes towards nature conservation. According to their research 'larger farmers were both more hostile (agro-businessmen) and more sympathetic (gentleman farmers) to conservation than farmers are in general' (Beedell and Rehman, 1999). We could assume that either there are cultural differences between farmers in Poland and in the Great Britain, or being aware of the sustainability concept does not have to be followed by certain attitudes toward the environment.

Average values of own capital, production, and farm income were also higher among those aware of the concept of sustainable development, although the difference was much lower. We could assume that farmers who work on larger scale could be more interested in broadening their knowledge connected not only with particular farming practices, but also more generally with current trends in agriculture. On the other hand, it is also possible that those who like to deepen their knowledge can achieve better financial results. Similarly, the soil quality differed significantly between these two groups of farmers.

The farmers who have heard of the concept had less animals, while having more land, which means their animal production was less intense. Similar conclusion can be drawn from the differences in the costs of mineral fertilisers. It is visible that farmers who have heard of the sustainability concept are relatively better educated. At the same time there were practically no differences when it comes to the farmers' age, time of managing the farm or having agricultural profile of education. There were also very small differences between the groups when it came to the farmers' neighbours complaining on their farms' on- erousness (those who have heard of sustainable agriculture faced the complaints slightly less often).

\section{CONCLUSIONS}

The results show that the farmers have a relatively high environmental awareness (at least in declarations). Most of them can see that potential influence of agriculture on the environment is rather negative. It is worth emphasizing that their knowledge of the sustainability concept is surprisingly high - most of the farmers that have heard of the concept were able to name properly its main features. This group had also visibly higher economic potential of the farms and was more likely to participate in agri-environmental programmes. These results seem promising when talking about implementing the idea of sustainable development in farming practice. Reducing the impact of farming on natural environment with simultaneous reaching economic and social goals will not be possible without farmers' cooperation, resulting from their knowledge and willingness to choose proper farming practices. Creating and implementing effective polices (dealing not only with environmental protection, but also with rural socio-economic development) should be based on the knowledge of farmers' awareness. The next step is to find the measures that would make farmers use this knowledge in practice.

\section{Acknowledgements}

The research is a part of project financed by $\mathrm{Na}-$ tional Science Centre, Poland 2015/19/B/HS4/02273 (Measuring relative performance of farms representing a different level of conformance with Sustainable Development).

\section{REFERENCES}

1. Beedell, J.D.C., Rehman, T. (1999). Explaining farmers' conservation behaviour: Why do farmers behave the way they do? Journal of Environmental Management, 57, pp. 165-176.

2. Carreón, J.R., Jorna, R., Faber, N., van Haren, R. (2011). A Knowledge Approach to Sustainable Agriculture. In: Draggan, Behnassi, M., Yaya, S. (eds.) Global Food Insecurity: rethinking agricultural and rural development paradigm and policy. Springer, Amsterdam, pp. 11-20. 
3. FADN (2008). Plan doboru próby gospodarstw rolnych Polskiego FADN [The sampling plan of Polish FADN]. Instytut Ekonomiki, Rolnictwa i Gospodarki Żywnościowej - Państwowy Instytut Badawczy, Warszawa.

4. Greiner, R. (2015). Motivations and attitudes influence farmers' willingness to participate in biodiversity conservation contracts. Agricultural Systems 137 , pp. 154-165.

5. van Herzele, A, Gobin, A., Van Gossum, P., Acosta, L., Waas, T., Dendoncker, N., de Frahan, B.H. (2013). Effort for money? Farmers' rationale for participation in agri-environment measures with different implementation complexity. Journal of Environmental Management, 131, pp. 110-120.

6. Kałuża, H. (2009). Świadomość ekologiczna rolników a zrównoważony rozwój rolnictwa. [Ecological awareness of farmers and sustainable development of agriculture]. Journal of Agribusiness and Rural Development, 3 (13), pp 63-71.

7. Kociszewski, K. (2013). Implementacja programu rolnośrodowiskowego w świetle teorii efektów zewnętrznych [Implementation of the agri-environmental programme in light of the external effects theory]. Roczniki Naukowe Ekonomii Rolnictwa i Rozwoju Obszarów Wiejskich, 100 (3), pp. 49-61.

8. Kostecka, J., Mroczek, J.R. (2007). Świadomość ekologiczna rolników a zrównoważony rozwój obszarów wiejskich Podkarpacia [Ecological awareness of far- mers and sustainable development of Podkarpacie rural areas]. Ekonomia i Środowisko, 2 (32), pp. 164-177.

9. Majewski, E., (2001). Jakość zarządzania w gospodarstwach rolniczych w Polsce w świetle badań [Quality of management in Polish farms in the light of studies]. Wydawnictwo SGGW, Warszawa.

10. Okumah, M., Martin-Ortega, J., Novo, P. (2018). Effects of awareness on farmers' compliance with diffuse pollution mitigation measures: A conditional process modelling. Land Use Policy, 76, pp. 36-45.

11. Sullivan, Sh., Mccann, E., De Young, R., Erickson, D. (1996). Farmers' Attitudes About Farming and the Environment: A Survey of Conventional and Organic Farmers. Journal of Agricultural and Environmental Ethics, 9 (2), pp. 123-143.

12. Waas, A. (2013). Modelowanie przemian strukturalnych polskiego rolnictwa [Modeling of structural changes in Polish agriculture]. Wydawnictwo SGGW, Warszawa.

13. World Commission on Environment and Development (1987). Our Common Future. Oxford University Press, Oxford.

14. Zegar, J.S. (2017). Cele społeczne w polityce zrównoważonego rozwoju rolnictwa i obszarów wiejskich [Social goals in the policy of sustainable development $\mathrm{o}$ agriculture and rural areas]. In: Zegar, J.St. (ed.) Z badań nad rolnictwem społecznie zrównoważonym [From the research on socially-sustainable agriculture] (39). Instytut Ekonomiki, Rolnictwa i Gospodarki Żywnościowej - Państwowy Instytut Badawczy, Warszawa. 